\title{
IMPROVISATIONAL THEATRE AS TEAM DEVELOPMENT INTERVENTION FOR CLIMATE FOR WORK GROUP INNOVATION
}

Authors:

Burgert Kirsten

Ronel du Preez ${ }^{1}$

\section{Affiliations:}

${ }^{1}$ Department of Industrial Psychology, Stellenbosch University, South Africa

\section{Correspondence to:}

Ronel du Preez

email:

rdp@sun.ac.za

\section{Postal address:}

Department of Industrial Psychology, Stellenbosch University, Private Bag

X1, Matieland 7602,

Stellenbosch, South Africa

\section{Keywords:}

innovation; group climate; group performance; improvisation; teambuilding

\section{Dates:}

Received: 30 Sept. 2009 Accepted: 14 Sept. 2010 Published: 15 Nov. 2010

How to cite this article: Kirsten, B., \& Du Preez, R. (2010). Improvisational theatre as team development intervention for climate for work group innovation. SA Journal of Industrial Psychology/SA Tydskrif vir Bedryfsielkunde, 36(1), Art. \#862, 9 pages. DOI: 10.4102/ sajip.v36i1.862

This article is available at:

http://www.sajip.co.za

(C) 2010. The Authors. Licensee: OpenJournals Publishing. This work is licensed under the Creative Commons Attribution License.

\section{ABSTRACT}

Orientation: Changes in business environments have resulted in a need for the development of innovative teams. Improvisational theatre as a technique could contribute to the understanding of how individuals can work together and be innovative.

Research purpose and motivation: This study evaluates the influence of a team development intervention utilising improvisational theatre exercises on innovative work group climate.

Research design, approach and method: A quasi-experimental non-equivalent control group design was employed with an experimental group and a control group from a healthcare managerial division.

Main findings: Repeated-measures ANOVA results indicated that for innovative work group climate as a whole, as well as for three of its factors, namely participative safety, vision, and task orientation, the experimental group's scores improved significantly $(p<0.05)$. Support for innovation did not show significant differences.

Practical/Managerial implications: This research has shown that improvisational theatre is a team development tool that can be used to assist work teams in creating a climate for innovation.

Contribution/value-add: This study extends the body of knowledge in the field of team building and highlights the contribution that improvisational theatre can make toward the development of work teams

\section{INTRODUCTION}

The world of work is characterised by constant change (Hansen \& Birkinshaw, 2007). These changes in business environments have resulted in major developments in organisational design with an emphasis on innovation (Anderson \& West, 1996; Waldersee, Griffiths \& Lai, 2003). The pursuit of creativity and innovation in products, services, systems and work processes have increasingly been recognised as a critical factor for long-term organisational survival and success (Ahmed, 1998; Amabile, 1988; Isaksen \& Tidd, 2006; Mathisen, Einarsen, Jorstad, \& Bronnick, 2004).

Researchers agree that working as part of a team plays a very important role in the process of innovation within organisations, as teams stimulate creativity and innovation (Anderson \& King, 1991; Hackman, 1987; King \& Anderson, 1990; Loo, 2003). King and Anderson (1990, p. 82) define group innovation as '... the emergence, import, or imposition of new ideas which are pursued towards implementation by the group through interpersonal discussions and successive re-mouldings of the original proposal over time'. West, Hirst, Richter and Shipton (2004) state that developing team innovation will improve an organisation's ability to adapt more quickly to the demands of change. Pirola-Merlo and Mann (2004) together with West et al. (2004) argue that to manage and implement change within organisations, an understanding of how to develop innovative teams is vital.

One of the factors that plays a crucial role in the innovation shown by teams is the climate for innovation within work groups (work groups and teams are used interchangeably for the purposes of this study) (West et al., 2004). Isaksen and Tidd (2006) propose that an innovative climate can be developed through development interventions. It is therefore argued that a work group's capacity to innovate can be increased by teaching group members the skills that foster the behaviour indicative of a climate for work group innovation. Despite the fact that work teams need to be innovative and develop a climate that supports innovation, little is known about how team members can learn these skills and successfully apply it in organisations (Vera \& Crossan, 2005). The principles of collective improvisation could provide insight into how team members can learn these skills and relate it to their work context. Vera and Crossan (2005) define improvisation occurring in teams as the creative and spontaneous process of attempting to accomplish an objective in a new way.

The role of improvisation in the field of innovation has attracted growing attention (Crossan, 1997, 1998; Crossan, Cunha, Vera \& Cunha, 2005; Kamoche, Cunha \& Cunha, 2003; Moorman \& Miner, 1998; Kanter, 2002; Vera \& Crossen, 2004, 2005; Weick, 1998). Innovation has an inherent improvisational nature and writers have long used jazz and rock music as a metaphor for describing the improvisational performance of innovators on project teams (Kanter, 2002; Vera \& Crossan, 2005; Weick, 1998). Vera and Crossan suggest that improvisation has a positive effect on team innovation when combined with team and contextual moderating factors such as teamwork quality, experimental culture, information sharing and communication and memory. They also provide evidence that team members, through training, can learn the skill of improvisation. 
Subsequently, academics have begun to investigate improvisational theatre in order to understand how individuals can work together in teams and be innovative (Crossan, 1997, 1998; Crossan, et al., 2005; Gibb, 2004; Kamoche, et al., 2003; Moshavi, 2001; Vera \& Crossen, 2004, 2005; Weick, 1998). Scholars have found that improvisational theatre incorporates a set of principles and characteristics and that these can be taught to organisational members through exercises that were originally designed to develop the improvisational skills of actors. Based on these exercises, training programmes have been developed to teach improvisational skills in organisations (Vera \& Crossan, 2004; 2005). As this technique is only in the foundation phase of development, limited literature and empirical evidence exist to support the effectiveness of these programmes (Vera \& Crossan, 2005). Thus, a need for sound theory development and empirical research in this field is evident.

\section{Purpose of the study}

This study aims to contribute to the need for sound theory development and empirical research in the field of improvisation training by providing empirical evidence to support the use of improvisational theatre techniques for enhancing climate for work group innovation. It also aims to contribute to the development of the existing theory in making explicit the link between the principles of improvisational theatre and the factors of climate for work group innovation.

\section{긍 Current theoretical perspectives \\ Climate for work group innovation \\ Work group climate refers to the shared perceptions of group members of a local work unit in terms of what is expected of them, work standards, recognition and their feelings about their manager and about one another (Anderson \& West, 1998; Michela \& Burke, 2002). In order to understand the shared climate for innovation, West's (1990) model is relevant as it is the leading and most studied model of work group climate for innovation. The model proposes that four factors, namely, (1) participative safety, (2) vision, (3) support for innovation and (4)} task orientation are predictive of innovation.

Participative safety: Participative safety is a psychological construct that supports an atmosphere within a work group which is perceived as interpersonally non-threatening and thereby motivates and reinforces involvement in decisionmaking. The work group's characteristic interpersonal processes are non-judgemental, non-threatening, trusting and supportive of the individual offering contributions and ideas and are characterised by socio-emotional cohesiveness (Anderson \& West, 1998; West, 1990). Participative safety constitutes four subfactors, namely, (1) safety, (2) information sharing, (3) interaction frequency and (4) influence (Anderson \& West, 1996). Safety is the degree to which team members are willing to take risks (Lowen \& Loo, 2004), whereas interaction frequency refers to how often team members meet to communicate both formally and informally (Anderson \& West, 1996). Information sharing refers to the degree that information is shared amongst team members (Anderson \& West, 1998; Lowen \& Loo, 2004) and influence indicates the degree to which decision-making is collective (Lowen \& Loo, 2004). The higher the level of each of these subordinate factors, the higher the level of participation in innovation and problem-solving would be within a work group (Anderson \& West, 1998).

Vision: An organisational vision is the expression of an idealised picture of the future (based on organisational values), which represents a higher order goal and provides motivation for members (Isaksen \& Tidd, 2006; West, 1990). For a work group to be innovative, it must have a shared vision and clearly defined objectives, as these provide direction and focus to the members' creative energy
(Anderson \& West, 1996, 1998; Mathisen et al., 2004). West (1990) explains work group vision in terms of four subfactors, namely, (1) sharedness, (2) attainability, (3) perceived value and (4) clarity.

Sharedness explains the level of general acceptance of the vision by individuals within the team, whereas attainability refers to the degree to which individuals feel that the team's objectives are within their reach to achieve. Perceived value is the extent to which the vision has a valued outcome for group members and thus produces commitment to group goals. Clarity describes the degree to which the vision is easy for the group members to understand (Anderson \& West, 1998; Lowen \& Loo, 2004; West, 1990).

Support for innovation: Support for innovation is defined as norms of innovation or the expectation, approval and practical support of more effective team processes (West, 1990; Lowen \& Loo, 2004). This supportiveness is similar to participative safety in that it involves feelings of safety, but it centres on the task (i.e. feeling safe to innovate) and not on interpersonal interactions (Pirola-Merlo, Härtel, Mann \& Hirst 2002). West (1990) distinguishes between the subfactors articulated and enacted support for innovation, seeing that many organisations express (i.e. articulate) support for the development of new and improved ways of working, but seldom provide (i.e. enact) practical support for their implementation. West's theory hypothesises that a high degree of articulated and enacted support for innovation will lead to more attempts to propose significant innovations. Support for innovation also implies a tolerance of error which will ensure that the innovator is not reprimanded when an attempt does not succeed (Amabile, 1988; West, 1990).

Task orientation: For a work group to be innovative, it requires clear standards of excellence characterised by individual commitment, motivation, self-esteem, individual performance and constant improvement (Isaksen \& Tidd, 2006). These standards indicate the degree to which the team is focused on reaching quality outcomes through critical evaluation of their own and others' inputs within a constructive framework (Pirola-Merlo et al., 2002). Task orientation encompasses three subfactors, namely, (1) excellence, (2) appraisal and (3) ideation (Anderson \& West, 1996). Excellence represents a concern among team members that the team should achieve the highest levels of performance, appraisal refers to mutual monitoring among team members to maintain a higher standard of work and ideation is the frequency with which members feel ideas are generated in the team. Ideation is characterised by team members building on each other's ideas to achieve the highest quality outcome (Anderson \& West, 1998; Lowen \& Loo, 2004).

West (1990) proposes that participative safety and support for innovation would primarily have a positive effect on the quantity of new ideas, seeing that they influence potential innovators through the creation of appropriate social reinforcement contingencies. Furthermore, vision and task orientation would primarily have a positive influence on the quality and significance of new ideas as they are more task or product oriented.

In order for a work group to increase its capacity for innovation, the members need to learn skills that promote the behaviours conducive of an innovative climate. However, little is known about how team members can learn these skills and successfully apply them in organisations (Vera \& Crossan, 2005). Crossan (1998) proposes that improvisation is one of the few tools available to organisations for developing their capacity to be innovative. The role of improvisation in the field of innovation has hence attracted growing attention from both academics and practitioners (Crossan, 1997, 1998; Crossan et al., 
2005; Kamoche et al., 2003; Moorman \& Miner, 1998; Kanter, 2002; Vera \& Crossen, 2004, 2005; Weick, 1998). The tradition of improvisation in the arts (i.e. music and theatre) has given a foundation for the development of improvisation theory. The emerging exercises have provided a link between theory and practice. Research findings by Vera and Crossan (2005) suggest that the same theatre principles that help actors to improvise are not only applicable in business settings, but can be learned and effectively applied by organisational members through training. Acknowledging that these skills can be developed is imperative to understanding team innovation and training.

\section{Improvisational theatre}

Improvisational theatre is a form of theatre that does not use a script or predetermined ideas for dialogue, direction or movement (Nevraumont, Hanson \& Smeaton, 2002). The performance is executed spontaneously and without any preconceptions in response to the immediate stimuli of the environment (Frost \& Yarrow, 1990). These stimuli include suggestions from the audience about the characters, location, situation and style of the scene and include offers made by fellow actors on stage (Nevraumont et al., 2002). In order to create successful performances, improvisational actors must therefore work together as a cooperative team (Frost \& Yarrow, 1990). Although improvisational theatre performances are unpredictable, this does not imply that they are without substantial structure or principles. These principles are trust and support, acceptance, listening and awareness and narrative skills. It is suggested here that these principles relate to the factors supportive of an innovative work group climate.

Trust and support: Izzo (1997) suggests that two of the most important concepts in improvisational theatre are trust and support. Trust is the reliance of an actor on the support and creativity of the others in the group. It includes trusting oneself, trusting the process of creativity and relinquishing control (Halpern, Close \& Johnson, 1994; Izzo, 1997). Support in improvisational theatre is explained by the phrase, '...make your fellow players look good' (Halpern et al., 1994, p. 43). This entails that when improvising actors get into difficulty (for example, when they struggle to develop the scene), they can trust that another actor will come to their assistance by accepting what they are offering in the form of a physical action or a verbal proposition and by developing these actions and verbal recommendations (Frost \& Yarrow, 1990).

Acceptance: Acceptance in improvisational theatre is also known as the 'yes, and' principle. When actors apply this principle, they accept the information given to them by other actors and build on it. It prevents one particular individual from dominating the scene and ensures that dialogue is dynamic (Crossan, 1998; Gladwel, 2006; Moshavi, 2001; Lowe, 2000). The rule of acceptance creates a climate wherein improvisers are required to accept, support and add to the ideas expressed by other actors on stage. In this climate, players feel safe to take risks (Vera \& Crossan, 2005). When an improviser rejects a fellow actor's idea, it is called a block. According to Frost and Yarrow (1990) blocking is regarded as unacceptable in improvisation. Ignoring or discarding an idea in improvisational theatre is not an option and can even be considered to be a form of aggression (Izzo, 1997; Johnstone, 1979).

Listening and awareness: The skills of listening and awareness in improvisational theatre are often referred to as being in the moment and it requires actors to pay attention to what is happening around them, to be present, alert and to concentrate (Izzo, 1997). A lack of attention and alertness while creating a story leads to conflict, incongruous actions and frustration for both the actors and the audience (Vera \& Crossan, 2005). Planning ahead and thinking about the direction actors would like a scene to follow mean that they are not attentive to what is happening in the present moment and that opportunities for discoverywould be missed (Halpern et al., 1994).
Narrative skills: The two narrative skills that actors need to develop in order to become accomplished improvisers are free association and reincorporation (Johnstone, 1979). Creativity and development are achieved through the use of free association (Frost \& Yarrow, 1990). Incorporation is the process that gives form to free association, whereas reincorporation is the repetition of a previously revealed bit of information, or a situation within a scene, that can provide closure and give form to developing scenes (Izzo, 1997). Therefore, while free association represents the nature of improvisation as creative and spontaneous, the rule of reincorporation reminds actors that improvisation does not mean 'anything goes', but rather that creating a coherent scene requires them to remember and reincorporate what was initiated before. This principle refers to the ensemble's memory of the present performance as well as lessons learned from previous performances (Frost \& Yarrow, 1990).

The use of themes is another narrative skill that ensures that improvised scenes are focused and coherent. A theme can be a headline, a topic or a direction that engages imagination and allows for the improvisation activity to start (Kanter, 2002).

All of these improvisational theatre principles help improvisational actors to work together to create successful performances. However, these principles cannot be learned adequately just from studying their processes and theory. They are learned experientially in the rehearsal room and on stage through exercises (Frost \& Yarrow, 1990; Gladwel, 2006; Izzo, 1997; Spolin, 1963). These exercises are not only applicable in the context of improvisational theatre, but can also be used as an experiential tool in organisational training (Crossen 1998; Keefe, 2003; Koppett, 2001; Lowe, 2000; Poynton, 2005; 2007; Vera \& Crossan, 2005).

\section{Improvisational training in organisations}

Background: Recent research results have shown that creativity and originality are neglected in the formal educational system (Beard \& Wilson, 2002). It has, however, been suggested that individuals can relearn to be creative and spontaneous (De Bono, 1982; 1990; Vera \& Crossan 2005). Improvisational theatre has shown that the potential to be creative and spontaneous can be rediscovered and developed through exercises. According to Izzo (1997) and Lowe (2000), creativity and spontaneity are improvisational skills and can be learned by anyone, as long as learners understand and apply themselves to the principles. Learning can take place during experiential training that incorporates theatre games and exercises (Frost \& Yarrow, 1990; Izzo, 1997; Spolin, 1963).

Process of improvisational training: Improvisational training involves the playing of theatre games designed to develop process skills (e.g. listening and communication), context-specific knowledge (a perspective and a context that enable team members to leave their comfort zone) as well as techniques that promote acceptance and shared responsibility (Crossan, 1998). Therefore improvisational theatre exercises provide a context wherein individuals can learn experientially the principles necessary for innovation. Teams develop through playing, seeing that bonds of communication are created between the playing members as well as through experiencing shared attitudes and behavioural patterns (Pirola-Marlo et al., 2002). Can it therefore be argued that a work group which is exposed to an improvisational theatre training programme would not only learn skills that would help the individual to be more innovative, but would also create shared attitudes and behaviours that could benefit the group as a whole? This question deserves note, as this study is concerned with whether or not climate for work group innovation, (as a shared attitude toward the work environment) would be influenced by improvisational interventions.

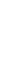


An improvisational training session usually begins with a short overview of the importance of improvisation to encourage individual investment of time and energy in the process. Individuals then work in small groups of 10-20 people with an experienced improvisation facilitator who takes them through a series of progressively more difficult improvisation exercises and provides instruction on the key principles of improvisation. After the participants have experienced the improvisational principles through the exercises, additional concrete links to the work environment are established through reflection (Crossan, 1998; Keefe, 2003).

Improvisation is a skill that can be learnt by applying oneself to the principles of improvisational theatre when playing theatre games (Frost \& Yarrow, 1990; Izzo, 1997; Spolin, 1963). Furthermore, the skill of improvisation promotes a group's capacity to innovate (Vera \& Crossan, 2005). Thus it is postulated that there is a decisive link between improvisation and climate for innovation, as both these concepts foster innovation.

The four principles of improvisational theatre (i.e. trust and support, acceptance, listening and awareness and narrative skills) relate in several ways to the four factors of climate for work group innovation (participative safety, vision, support for innovation and task orientation). Participative safety and support for innovation ensure that a work group generates a quantity of new ideas, while vision and task orientation ensure that the quality of the ideas are of a good standard (West, 1990). Similarly, trust and support and acceptance in improvisational theatre ensure that actors can be spontaneous, reincorporation ensure that the spontaneous ideas of the actors have structure and direction. These similarities are indicated in Table 1.

The following hypotheses are thus investigated:

- hypothesis 1

- hypothesis 2

- hypothesis 3

- hypothesis 4

- hypothesis 5 .

Hypothesis 1: A team development intervention based on improvisational theatre exercises will have a positive influence on climate for work group innovation.

Hypothesis 2: A team development intervention based on improvisational theatre exercises will have a positive influence on the factor participative safety of climate for work group innovation

Hypothesis 3: A team development intervention, based on improvisational theatre exercises, will have a positive influence on the factor vision of climate for work group innovation.
Hypothesis 4: A team development intervention based on improvisational theatre exercises will have a positive influence on the factor support for innovation of climate for work group innovation

Hypothesis 5: A team development intervention based on improvisational theatre exercises will have a positive influence on the factor task orientation of climate for work group innovation.

A positive influence is regarded as an increase in the specific factor as contributor towards the climate for work group innovation.

\section{RESEARCH DESIGN}

\section{Research approach}

A quasi-experimental design, specifically a non-equivalent control group design, was used. This type of design involves an experimental group and a control group that both complete a pre-test and a post-test, but the two groups do not have preexperimental sampling equivalence (as the participants are not randomly assigned to the groups) (Campbell \& Stanley, 1963; Goldstein, 1993). Random selection of the participants would have been neither possible nor useful in the study presented here, as the climate for work group innovation was to be measured for an already established unit.

\section{Research method}

\section{Research participants}

Two teams from the healthcare management division (which formed part of the healthcare department of a large insurance company in South Africa) were selected for the purposes of this study. Each team consisted of 20 members. The demographic profile of the team members are not reported here as the focus was on teams' climate for innovation. The team profiles are reported in the subsequent paragraphs.

The experimental group was responsible for the management of clinical risk in hospitalised members of medical schemes and the control group's responsibility involved the management of clinical risk in non-hospitalised members. Innovation plays an important role in the day to day tasks of these teams as they need to develop new and more efficient systems to deal with constantly changing technology, such as new computer software and telecommunication. Furthermore, they need to adapt to changing medical scheme policies and new medicine entering the market.

The two teams' day-to-day tasks were similar, making the equivalence of the two groups greater. The teams functioned

TABLE 1

A comparison between climate for work group innovation factors and principles of improvisational theatre

Climate for work group innovation factors and subfactors

\begin{tabular}{|c|c|c|c|c|}
\hline \multirow[b]{2}{*}{ Improvisational theatre principles } & \\
\hline & Participative safety & Support for innovation & Vision & Task orientation \\
\hline & Safety & - & Clarity & - \\
\hline & Interaction frequency & Articulated support & Attainability & Excellence \\
\hline & Information sharing & Enacted support & Perceived value & Appraisal \\
\hline & Influence & - & Sharedness & Ideation \\
\hline Trust and support & $\begin{array}{l}\text { Interactive atmosphere } \\
\text { characterised by trust and support }\end{array}$ & $\begin{array}{l}\text { Members can trust that ideas will } \\
\text { be supported }\end{array}$ & - & - \\
\hline Acceptance & $\begin{array}{l}\text { Non-judgemental and supporting } \\
\text { experimentation }\end{array}$ & Tolerance for error & - & Building on ideas \\
\hline Listening and awareness & $\begin{array}{l}\text { Effective communication and } \\
\text { information sharing }\end{array}$ & - & - & - \\
\hline Narrative skills & - & - & Gives direction and focus to ideas & $\begin{array}{l}\text { Ensures ideas are appropriate } \\
\text { and focussed }\end{array}$ \\
\hline
\end{tabular}


TABLE 2

Repeated-measures ANOVA results

\begin{tabular}{lll}
\hline Factor & Time $\boldsymbol{x}$ group $(p)$ & $\boldsymbol{F}$ \\
\hline Climate & $0.03^{*}$ & 5.16 \\
Participative safety & $0.05^{*}$ & 4.25 \\
Safety & $0.004^{* *}$ & 9.92 \\
Information sharing & $0.03^{*}$ & 5.23 \\
Interaction frequency & 0.32 & 1.03 \\
Influence & 0.61 & 0.27 \\
Vision & $0.046^{*}$ & 4.37 \\
Sharedness & $0.04^{*}$ & 4.58 \\
Attainability & 0.64 & 0.22 \\
Perceived value & $0.04^{*}$ & 4.94 \\
Clarity & 0.09 & 3.16 \\
Support for innovation & 0.88 & 0.02 \\
Task orientation & $0.02^{*}$ & 5.99 \\
Excellence & 0.27 & 1.29 \\
Appraisal & 0.10 & 2.93 \\
Ideation & $0.02^{*}$ & 6.40 \\
\hline
\end{tabular}

${ }^{*} p \leq 0.05 ; F$, F-ration

separately from each other, resulting in each team having their own climate, while the greater organisational climate and culture was similar. The group sizes (which included 10-20 individuals) were also ideal for the chosen type of intervention (Crossan, 1998). The sizes and similarities between the two groups thus made them ideal for the current study.

\section{Measuring instrument}

The Team Climate Inventory (TCI) developed by Anderson and West (1994) was used as the measuring instrument. According to Mathisen and Einarsen (2004), the TCI serves as a team development tool capable of facilitating interventions related to innovation in work groups. The TCI is a fivefactor, 44-item, multi-dimensional instrument with acceptable psychometric properties (Anderson \& West, 1996, 1998). Validity studies for the TCI were conducted in different types of organisations, which make the TCI a very useful instrument that can be applied to teams in diverse settings (Mathisen \& Einarsen, 2004). Anderson and West (1998) present data confirming the underlying factor structure, internal homogeneity, predictive validity and factor replicability across groups for the TCI.

The TCI has been translated and tested in five European languages. Results from internal homogeneity tests (Cronbach's alpha) consistently suggest that the reliability of the TCI is acceptable, with alphas above the generally excepted value of 0.70 (Pallant, 2001, p. 85). In the current study the Cronbach alpha coefficient ranged between 0.81 and 0.92 .

\section{Research procedure}

The pre-test was administered to both the experimental and the control group one day prior to the intervention. Sixteen members from each group completed the questionnaire used for the pre-test $\left(n_{e}=16\right.$ and $\left.n_{c}=16\right)$. On the following day, the experimental group was exposed to the team development intervention. Unfortunately, the manager of the team was not available to take part in the intervention.

It is difficult to determine the time period necessary between the intervention and the post-test (Goldstein, 1993). However, the post-test should be administered after the participants had been in the transfer situation for a '... reasonable time' period (Goldstein, 1993, p.150). The post-test was conducted eight weeks after the intervention on both the experimental $\left(n_{e}=15\right)$ and the control group $\left(n_{c}=13\right)$.

\section{Analysis of data}

The data was analysed using STATISTICA (Statsoft Inc., Tulsa, Oklahoma, 2008). Item analyses were performed on all the subscales to determine internal consistency. The influence of the intervention on climate for innovation was determined by performing a repeated-measures ANOVA analysis on the data from the pre-test and post-test for the experimental group and control group. The time-by-group interaction effect hypothesis states that the change over time will be equal for all groups. Repeated-measures ANOVAs were performed on climate for innovation (climate) as a whole as well as on the four super ordinate scales and the 13 subordinate scales. The post hoc Bonferroni multiple comparisons test was performed when a null hypothesis was rejected in the above analysis.

\section{RESULTS}

For the purposes of this study, a significant time-by-group interaction effect is the most important result, indicating that there is a significant difference between the pre-test and post-test scores for the experimental and the control group. The significance of the time-by-group interaction for all the variables is shown in Table 2.

The climate results from the repeated-measures ANOVA indicate a significant time-by-group interaction at the $5 \%$ confidence level ( $p=0.03$ ) (refer to Table 2). The time-by-group interaction is graphically depicted in Figure 1, indicating that the one group's climate score had changed significantly from the pre-test to the post-test in comparison with the other group. The results from the Bonferroni test (refer to Table 4) indicate that there is a positive difference between the experimental group's pre-test and post-test climate means at the $1 \%$ significance level $(p=$ $0.005)$. This is in contrast to the difference between the control group's pre- and post-test means which show no significant difference $(p=1)$. With that, null hypothesis 1 is rejected.

A significant time-by-group interaction effect is indicated at the $5 \%$ confidence level $(p=0.05)$ for participative safety (refer to Table 2). The time-by-group interaction is graphically depicted in Figure 2. The Bonferroni results (refer to Table 4) indicate that the experimental group's participative safety score improved from the pre-test to the post-test. This improvement is only marginally above the $5 \%$ level of confidence $(p=0.06)$. The control group's score does not show any significant difference ( $p$ $=1$ ). Null hypothesis 2 is thus rejected. The subfactors safety ( $p=$ $0.004)$ and information sharing ( $p=0.03)$ show significant timeby-group interaction effects (refer to Table 2). The Bonferroni results indicate that the difference lay in the experimental group's pre- and post-test mean scores for these two subfactors $(p=0.06 ; p=0.03)$. Table 2 indicates that the subfactors interaction frequency and influence reveal no significant time-by-group interaction $(p=0.32 ; p=0.61)$.

The ANOVA results for vision indicate a significant time-bygroup interaction effect at the $5 \%$ level $(p=0.046)$ (refer to Table

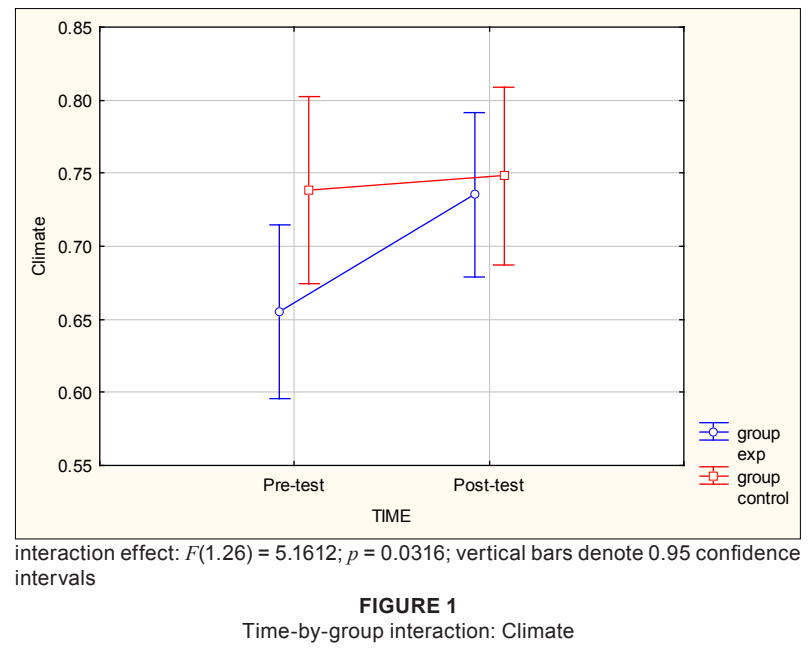

西

\%


TABLE 3

Bonferroni results: Climate

\begin{tabular}{lllllll}
\hline Cell no. & Group & Time & (1) & (2) & (3) & (4) \\
& & Mean & 0.66 & 0.74 & 0.74 & 0.75 \\
\hline 1 & Exp. & Pre-test (1) & - & $0.005^{* *}$ & 0.31 & 0.19 \\
2 & Exp. & Post-test (2) & - & - & 1.00 & 1.00 \\
3 & Control & Pre-test (3) & - & - & - & 1.00 \\
4 & Control & Post-test (4) & - & - & - & - \\
\hline$* p \leq 0.05 ; * * p \leq 0.01 ;$ Exp, experimental & & & &
\end{tabular}

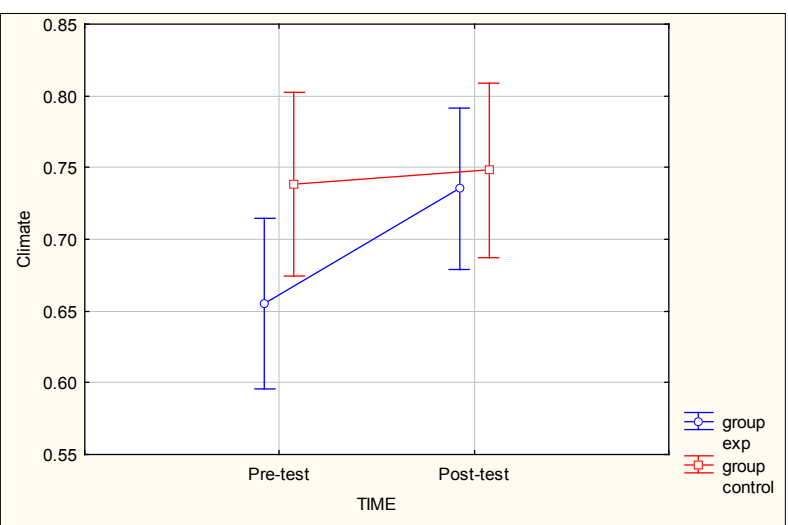

nteraction effect: $F(1.26)=5.1612 ; p=0.0316$; vertical bars denote 0.95 confidence intervals

FIGURE 2

Time-by-group interaction: Participative safety

2). The time-by-group interaction is graphically illustrated in Figure 3. The Bonferroni test results (refer to Table 5) indicate that there was no significant improvement in the experimental group's pre- to post-test scores at the $5 \%$ level. The difference is, however, marginally higher than $0.05(p=0.058)$. The control group's score did not change significantly from the pre-test to the post-test $(p=1)$. Thereby null hypothesis 3 is rejected. The subfactors sharedness and perceived value both reveal significant time-by-group interaction effects at the $5 \%$ level $(p$ $=0.04$ for both subfactors). The Bonferroni results indicate that the difference for sharedness lay in the experimental group's mean scores $(p=0.04)$. Perceived value, however, did not show a significant improvement for the experimental group $(p=0.31)$ The subfactors attainability and clarity show no significant timeby-group interaction $(p=0.64 ; p=0.09)$.

No significant time-by-group effect was found for support for innovation at the 5\% level (refer to Table 2). Support for innovation and its subfactors were therefore not positively influenced by the intervention. Null hypothesis 12 is accepted.

Table 2 depicts a significant time-by-group interaction effect at the $5 \%$ level $(p=0.02)$ for task orientation. Refer to Figure 4 for a graphic illustration of the time-by-group interaction. The Bonferroni analysis (refer to Table 6) indicates that the experimental group's task orientation score improved significantly at the $1 \%$ level from the pre-test to the post-test $(p=0.001)$. The control group's mean scores did not change significantly from the pre-test to the post-test $(p=1)$. Null hypothesis 5 is therefore rejected. The subfactor excellence shows no significant time-by-group interaction effect ( $p=$ $0.27)$. The time-by-group interaction for the subfactor appraisal shows a trend, as it is significant at the $10 \%$ level $(p=0.10)$. The Bonferroni analysis, however, indicates that the experimental group's score improved significantly at the $1 \%$ level $(p=$ 0.006 ), whereas the control group's score do not indicate a statistically significant change $(p=1)$. The subfactor ideation reveals a significant time-by-group interaction effect $(p=0.02)$. According to the Bonferroni results the experimental group's improvement was not statistically significant at the $5 \%$ level. It was, however, significant at the $10 \%$ level, which is indicative of a trend $(p=0.09)$.
TABLE 4

Bonferroni results: participative safety

\begin{tabular}{lllllll}
\hline Cell no. & Group & Time & (1) & (2) & (3) & (4) \\
& & Mean & 40.36 & 45.27 & 44.46 & 44.00 \\
\hline 1 & Exp. & Pre-test (1) & - & 0.06 & 0.82 & 1.00 \\
2 & Exp. & Post-test (2) & - & - & 1.00 & 1.00 \\
3 & Control & Pre-test (3) & - & - & - & 1.00 \\
4 & Control & Post-test (4) & - & - & - & - \\
\hline$* p \leq 0.05 ;$ & $* * p \leq 0.01 ;$ Exp, experimental & & & &
\end{tabular}
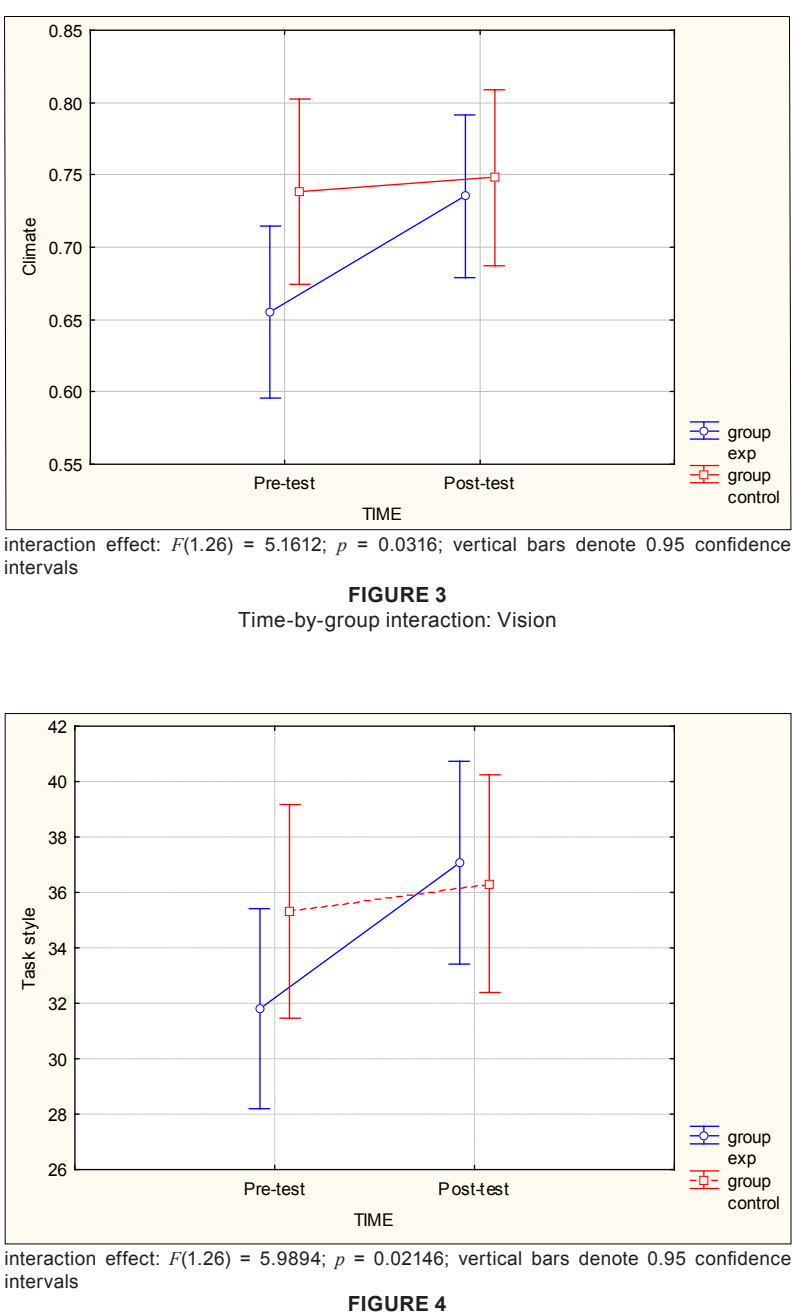

Time-by-group interaction: Task orientation

TABLE 5

Bonferroni results: Vision

\begin{tabular}{lllllll}
\hline Cell no. & Group & Time & (1) & (2) & (3) & (4) \\
& & Mean & 51.17 & 58.07 & 62.08 & 61.39 \\
\hline 1 & Exp. & Pre-test (1) & - & 0.058 & $0.05^{*}$ & 0.07 \\
2 & Exp. & Post-test (2) & - & - & 1.00 & 1.00 \\
3 & Control & Pre-test (3) & - & - & - & 1.00 \\
4 & Control & Post-test (4) & - & - & - & - \\
\hline${ }^{*} p \leq 0.05 ;$ & $* * p \leq 0.01 ;$ Exp, experimental & & &
\end{tabular}

TABLE 6

Bonferroni results: Task orientation

\begin{tabular}{lllllll}
\hline Cell no. & Group & Time & (1) & (2) & (3) & (4) \\
& & Mean & 31.80 & 37.07 & 35.31 & 36.31 \\
\hline 1 & Exp. & Pre-test (1) & - & $0.001^{* *}$ & 1.00 & 0.54 \\
2 & Exp. & Post-test (2) & - & - & 1.00 & 1.00 \\
3 & Control & Pre-test (3) & - & - & - & 1.00 \\
4 & Control & Post-test (4) & - & - & - & - \\
\hline$* p<0.05 ;$ & $* * p<0.01$ Exp, experimental
\end{tabular}




\section{DISCUSSION}

The aim of this study was to determine whether an improvisational theatre team development intervention would have a positive influence on climate for work group innovation as a whole. Furthermore, the influence of the intervention on the four sub-factors of work group innovations was investigated. The results indicate that the intervention had a positive influence on climate for work group innovation as a whole due to the impact made on the sub-factors participative safety, vision and task orientation. This contributes to the body of knowledge in the field of team building and the contribution that improvisational theatre could make to the development of work group innovation.

Participative safety was positively impacted by the intervention because of the intervention's influence on information sharing and safety. The intervention had no impact on influence and interaction frequency. A possible reason for this outcome is that, when the improvisational principle of acceptance is applied, it creates an atmosphere wherein members feel psychologically safe to participate and that sharing ideas will not lead to an attack, censorship, ridicule or penalisation (West, 1990; Vera \& Crossan, 2005; Izzo, 1997). Therefore, if group members applied the principle of acceptance, it would not necessarily have an influence on the frequency of their interaction and the amount of influence that took place, but the members would feel safer to participate and therefore more information would be shared when they interact. The principle of listening and awareness also relates mostly to information sharing, seeing that it helps individuals to communicate more effectively. This could explain why the intervention only had an impact on safety and information sharing and not on interaction frequency and influence.

It can be concluded from the results for vision and its subordinate factors, that vision was positively influenced by the intervention; however, the influence was weak, as a significant influence could only be reported on sharedness. The intervention did not have a significant influence on the other subordinate factors, namely perceived value, attainability and clarity. The objective of the exercises in the intervention focusing on vision was specifically developed to create a shared reality and a common vision through team acceptance (Gesell, 1997). This could explain the significant influence of the intervention on sharedness, because this factor refers to the level of general acceptance of the vision by individuals within a team (Anderson \& West, 1998; Lowen \& Loo, 2004).

The results regarding support for innovation indicate that this factor was not significantly influenced by the intervention. One possible explanation could be the lack of managerial participation in the intervention. According to West (1990), those in positions of authority often have more influence on norms than subordinates do; therefore group leaders are likely to be more influential in supporting group innovation. For this reason, the absence of the group manager could have impacted on the support for innovation; no subsequent significant improvement from the pre-test to the post-test could be attained. It could be argued that a manager influences all the other factors of an innovative climate and that those factors therefore should not have changed significantly after the intervention. However, it is put forward here that support for innovation is much more likely to be influenced by leadership than the other three factors, although this notion could not be substantiated from the available literature. West et al. (2003) posit that it has not been explored sufficiently whether and how leadership impacts on team innovation. However, in the model of climate for work group innovation, West (1990) emphasises the importance of leadership for support for innovation more than for the other factors.
We believe that the intervention had a positive influence on task orientation. The subordinate factors appraisal and ideation were impacted on, whereas excellence did not show any influence. The fact that only appraisal and ideation (and not excellence) were influenced could be attributed to the fact that the improvisational principles taught by the intervention relate to these two factors. Acceptance relates to ideation, as both concepts refer to the acceptance of others' ideas and the act of building on these ideas. Narrative skills relate to appraisal. Appraisal refers to mutual monitoring amongst team members to maintain a higher standard of work; narrative skills remind the actors that not every spontaneous idea is necessarily appropriate and requires them to remember and reincorporate what had been initiated in the past in an attempt to create the best scenes (Anderson \& West, 1996; Izzo, 1997; Vera \& Crossan, 2005).

\section{Conclusions, recommendations and implications for practice}

These findings support the assumptions of academics and practitioners who suggest that the principles of improvisational theatre can add value to teams' capacity to be innovative (Crossan, 1997; 1998; Crossan, et al., 2005; Gesell, 1997; Gibb, 2004; Kamoche et al., 2003; Koppett, 2001; Lowe, 2000; Moshavi, 2001; Poynton, 2007; Vera \& Crossen, 2004. 2005). Furthermore, support is indicated for findings suggesting that improvisation has a positive effect on team innovation when combined with team and contextual moderating factors and that improvisational skills can be learned by organisational members through training (Vera \& Crossan, 2005). The notion that exercises used by improvisational actors to develop their skill can be adopted by business as a means to experience and enhance individual and organisational capacity to be innovative is also maintained (Crossan, 1997).

\section{Limitations}

The size of the groups and the number of groups limited the reliability of the results. Furthermore, the analysis of pre-test and post-test gain scores is normally inappropriate for nonequivalent control group designs, as the internal threats to validity may have resulted in a type I error (Cook \& Campbell, 1979). Four threats to internal validity, namely (1) the interaction between selection and maturation, (2) instrumentation, (3) statistical regression and (4) interaction between selection and history were taken into consideration. To the best of our knowledge, it is therefore concluded that the significant positive change in climate, participative safety, vision and task orientation for the experimental group can be ascribed to the intervention. However, since the size and direction of some biases will always be unknown in social science studies where randomisation is not present, the conclusion should be regarded as tentative (Cook \& Campbell, 1979).

Research on the use of improvisational theatre exercises in organisational training settings is still in an early stage of development. The findings of this study build on the findings of limited previous research and so contribute to the existing body of knowledge. While this study points to the short-term benefits of improvisational theatre interventions, further research is needed to confirm the long-term benefits.

\section{Future research endeavours}

Prospective research could investigate the role of leadership and leadership participation in fostering a climate for work group innovation. The effectiveness of the various individual improvisational theatre exercises need to be studied to determine which of these should be included in future training and development interventions. A replication of the study on a larger sample and in another industry, together 
with the implementation of a time-series design to provide for transfer of skills, could provide support for the initial findings of this study. A further need would be the development and validation of a measurement instrument that measures improvisational skills. It is also suggested that future studies should include a qualitative research method in order to capture possible data lost due to the quantitative nature of the questionnaire.

This research has shown that the use of improvisational theatre exercises has a meaningful impact on climate for work group innovation. Improvisational theatre becomes a team development tool that can be used for assisting work teams in becoming more innovative. This is a contribution that is not only of importance in extending the body of knowledge in the field of team-building, it is also important for sound business practice. Greater innovation in work teams result in greater innovation in companies - innovative companies respond more effectively to the demands of an ever-changing world of work.

\section{REFERENCES}

Agrell, A., \& Gustafson, R. (1994). The Team Climate Inventory (TCI) and group innovation: A psychometric test on a Swedish sample of work groups. Journal of Occupational and Organizational Psychology, 67, 143-151.

Ahmed, P.K. (1998). Culture and climate for innovation. European Journal of Innovation Management, 1, 30-43.

Amabile, T.M. (1988). A model of creativity and innovation in organisations. Research in Organisational Behaviour, 10, 123167.

Anderson, A., \& West, N. (1996). The Team Climate Inventory: Development of the TCI and its applications in teambuilding for innovativeness. European Journal of Work and Organizational Psychology, 5(1), 3-66.

Anderson, A., \& West, N. (1998). Measuring climate for work group innovation: Development and validation of the team climate inventory. Journal of Organizational Behavior, 19, 235258.

Anderson, N.R., \& King, N. (1991). Managing innovation in organisations. Leadership and Organization Development Journal, 12(4), 17-21.

Beard, C., \& Wilson, J.P. (2002). The power of experiential learning: A handbook for trainers and educators. London: Kogan Page.

Campbell, D.T., \& Stanley, J.C. (1963). Experimental and quasiexperimental research designs. Chicago: Rand McNally College Publishing Company.

Cook, T.D., \& Campbell D.T. (1979). Quasi-experimentation: Design and analysis issues for field settings. Boston: Houghton Miffin Company.

Crossan, M. (1997). Improvise to innovate. Ivey Business Journal, 62(1), 36-42.

Crossan, M. (1998). Improvisation in action. Organization Science, 9(5), 593-599.

Crossan, M., Cunha, M., Vera, D., \& Cunha, J. (2005). Time and organisational improvisation. Academy of Management Review, 30(1), 129-145.

De Bono, E. (1982). Lateral thinking. Harmendworth: Penguin Books.

De Bono, E. (1990). Lateral thinking for management: A handbook. London: Penguin Books.

Frost, A., \& Yarrow, R. (1990). Improvisation in Drama. New York: St Martin's Press.

Gesell, I. (1997). Playing along: 37 group learning activities borrowed from improvisational theater. Duluth, Minnesota: Whole Person Associates.

Gibb, S. (2004). Arts-based training in management development: The use of improvisational theatre. Journal of Management Development, 23(8), 741-750.

Gladwel, M. (2006). Blink: The power of thinking without thinking. London: Penguin.
Goldstein, I.L. (1993). Training in organisations: Needs assessment, development and evaluation (3rd edn.). Pacific Grove: Brooks/ Cole Publishing Company.

Halpern, C., Close, D., \& Johnson, K. (1994). Truth in comedy: The manual of improvisation (1st edn.). Colorado Springs: Meriwether Publishing.

Hansen, M.T., \& Birkinshaw, J. (2007). The innovation value chain. Harvard Business Review, June 2007, 1-12.

Isaksen, S., \& Tidd, J. (2006). Meeting the innovation challenge: Leadership for transformation and growth. Chichester, England: John Wiley \& Sons, Ltd.

Izzo, G. (1997). The art of play: The new genre of interactive theatre Portsmouth: Heinemann.

Johnstone, K. (1979). Impro: Improvisation and the Theatre. New York: Theatre Arts Books.

Kamoche, K., Cunha, M., \& Cunha. J. (2003). Towards a theory of organisational improvisation: Looking beyond the jazz metaphor. Journal of Management Studies, 40, 2023-2051.

Kanter, R.M. (2002). Strategy as improvisational theatre. MIT Sloan Management Review, Winter, 76-81.

Keefe, J.A. (2003). Improve yourself: Business spontaneity at the speed of thought. Hoboken, New Jersey: John Wiley \& Sons Inc.

King, N., \& Anderson, N. (1990). Innovation in working groups. In M.A. West \& J.L. Farr (Eds.), Innovation and creativity at work: Psychological and organizational strategies, (pp. 81-101). London: John Wiley.

Kivimäki, M., Kuk, G., Elovainio, M., Thomson, L., KalliomakiLevanto, T., \& Heikkila, A. (1997). The Team Climate Inventory: Four or five factors? Journal of Occupational and Organizational Psychology, 70, 375-389.

Koppett, K. (2001). Training to imagine: Practical improvisational theatre techniques to enhance creativity, leadership, teamwork and learning. Sterling: Stylus Publishing.

Lowe, R. (2000). Improvisation Inc.: Harnessing spontaneity to engage people and groups. San Francisco: Jossey-Bass/Pfeiffer and Creative Training Techniques Press.

Lowen, P., \& Loo, R. (2004). Assessing team climate by qualitative and quantitative approaches. The Learning Organization, 11(3), 260-272

Mathisen, G., \& Einarsen, S. (2004). A review of instruments assessing creative and innovative environments within organizations. Creativity Research Journal, 16(1), 119-140.

Mathisen, G., Einarsen, S., Jorstad, K., \& Bronnick, K.S. (2004). Climate for work group creativity and innovation: Norwegian validation of the team climate inventory. Scandinavian Journal of Psychology, 45, 383-392.

Michela, J.L., \& Burke, W. (2000). Organizational culture and climate in transformations for quality and innovation. In N.M. Ashkanasy, C.P.M. Wilderom, \& M.F. Peterson (Eds.), Handbook of Organizational Culture and Climate, (pp. 225-244). Thousand Oaks: Sage Publications.

Moorman, C., \& Miner. A. (1998). The convergence of planning and execution: Improvisation in new product development. Journal of Marketing, 62(3), 1-20.

Moshavi, D. (2001). 'Yes and ...': Introducing improvisational theatre techniques to the management classroom. Journal of Management Education, 25(4), 437-49.

Nevraumont, E.J., Hanson, N.P., \& Smeaton, K. (2002). The ultimate improv book: A complete guide to comedy improvisation. Colorado Springs: Meriwether Publishing.

Pallant, J. (2001). SPSS survival manual: A step by step guide to data analysis using SPSS for Windows (version 10). Buckingham, Philadelphia: Open University Press.

Pirola-Merlo, A., \& Mann, L. (2004). The relationship between individual creativity and team creativity: Aggregating across people and time. Journal of Organizational Behavior, 25, 235-257.

Pirola-Merlo, A., Härtel, C., Mann, L., \& Hirst, G. (2002). How leaders influence the impact of affective events on team climate and performance in R\&D teams. The Leadership Quarterly, 13, 561-581. 
Poynton, R. (2005). Improvisational theatre: Alternative ways to engage with reality. Convergence, 6(4), 64-67.

Poynton, R. (2007). Show up and listen: Improvisational theatre offers lessons for today's uncertainties. HR Future, 3(51), $51-52$

Ragazzoni, P., Baiardi, P., Zotti, A. M., Anderson, N., \& West, M. (2002). Italian validation of the team climate inventory: A measure for team climate for innovation. Journal of Managerial Psychology, 17(4), 325-336.

Reichardt, C.S. (1979). The statistical analysis of data from nonequivalent group designs. In T.D Cook \& D.T. Campbell (eds.), Quasi-experimentation: Design and analysis issues for field settings, (pp. 147-206). Boston: Houghton Miffin Company.

Spolin, V. (1963). Improvisation for the Theatre. Evanston: North Western University Press.

Statsoft Inc. (2008). STATISTICA version 8.0 [data analysis software system]. Tulsa: Statsoft Inc.

Tannenbaum S.I., \& Yukl, G. (1992). Training and development in work organizations. Annual Reviews Psychology, 43, 399441

Vera, D., \& Crossan, M. (2004). Theatrical improvisation: Lessons for organisations. Organization Studies, 25(5), 727-749.
Vera, D., \& Crossan, M. (2005). Improvisation and innovative performance in teams. Organization Science, 16(3), 203224

Waldersee, R., Griffiths, A.B., \& Lai, J. (2003) Predicting organizational change success: Matching organization type, change type and capabilities. The Journal of Applied Management and Entrepreneurship, 8(1), 66-81.

Weick, K.E. (1998). Improvisation as a mindset for organizational analysis. Organization Science, 9(5), 543-555.

West, M.A. (1990). The social psychology of innovation in groups. In M.A. West \& J. L. Farr (Eds.), Innovation and creativity at work: Psychological and organizational strategies, (pp. 309-333). London: John Wiley.

West, M.A., Borrilla, C.S., Dawson, J.F., Brodbecka, F, Shapiro, D.A., \& Haward, B. (2003). Leadership clarity and team innovation in health care. The Leadership Quarterly, 14, 393410.

West, M.A., Hirst, G., Richter, A., \& Shipton, H. (2004). Twelve steps to heaven: Successfully managing change through developing innovative teams. European Journal of Work and Organizational Psychology, 13 (2), 269-299. 